\title{
Analyses of the Chemical Composition of the Extracts of Bee Brood and Adult Bees
}

\author{
Maria POJAR-FENESAN ${ }^{1) *}$, Ana BALEA ${ }^{1)}$, Irina CIOTLAUS $^{1)}$ and Mirela MICLEAN ${ }^{2)}$ \\ 1)“Babeș-Bolyai” University - "Raluca Ripan” Institute for Research in Chemistry, 30 Fantanele street \\ 400294 Cluj-Napoca, Romania \\ 2) INCDO-INOE 2000, Research Institute for Analytical Instrumentation, 67 Donath street, 400293 Cluj- \\ Napoca, Romania \\ *Corresponding author, e-mail: mariafenesan@gmail.com
}

Bulletin UASVM Animal Science and Biotechnologies 72(2) / 2015

Print ISSN 1843-5262; Electronic ISSN 1843-536X

DOI:10.15835/buasvmcn-asb:11459

\begin{abstract}
Living organisms in the beehive communicate by chemical language. The study of the chemical composition of bee brood extracts and adult bees is interesting assuming as bee brood emissions could be "words" in the "dialogues" in the hive.

This study proposes an analysis of the composition of worker bee brood and drone brood extracts, using different solvents. The bioassays start with GC-MS analysis of various extracts obtained by dissolving biological material (bee brood, adult bees) in different solvents (ethylic ether, hexane, pentane, aqueous solution, brine). The substances found in these extracts that could be kairomones are fatty acids (9-Octadecenoic acid and Hexadecanoic acid) and methyl ester fatty acid, 2-methyl propionic acid, hydrocarbons with long chain (Heptacosane, Octacosane). "Communication" by some of these substances will be used for the behavioural studies of the bees' enemy mite, Varroa destructor.
\end{abstract}

Keywords: Bee brood, GC-MS, semiochemicals

\section{INTRODUCTION}

Studies regarding the chemical composition of the biological material obtained from bee brood and adult bees are interesting in the context of inter-specific communication from the hive using semiochemicals (from the Greek semeon, meaning "signal" , a chemical substance or mixture that carries a message for purposes of communication www.dictionaryofforestry.org/dict/term / semiochemical).

Bee brood emissions are "words" in the "dialogues" in the life of the hive during feeding, brood care, hygienic behavior and cell invasion by the mite Varroa destructor (Garrido and Rosenkranz, 2004; Palacio et al., 2010).

The aim of the GC-MS analyses is to find possible pheromonal structures that could be used for treating Varroa mite infestation in the hive. This study proposes an analysis of the composition of worker bee brood and drone brood extracts, using different solvents.

\section{MATERIALS AND METHODS}

The biological material, bee brood aged 8-10 days was collected from an apiary located in Caianu area, Cluj County on May 3, 2015. For each extraction, 20 larvae were used. Extraction techniques presented in this article involve the removal of the larvae from the cell environment and the addition of a solvent. Extraction time is 20 hours followed by filtration and concentration of the solvent in a current of nitrogen.

GC-MS Model (AGILENT 7890 \& 5975 Series MSD) was used for analysis. For qualitative determination, the MS system was operated in SCAN mode. The carrier gas was helium at a constant flow rate of $1 \mathrm{~mL} / \mathrm{min}$. The GC column was HP-5MS, with the initial temperature of the 


\section{RESULTS AND DISCUSSION}

Tab. 1. The main compounds identified in the various extracts

\begin{tabular}{|c|c|c|c|}
\hline No. & Biological material & Extraction methods / & Identified compounds \\
\hline & & Solvent used & \\
\hline \multirow[t]{4}{*}{1} & Worker bee brood & Diethyl ether & 9-Octadecenoic acid \\
\hline & & & Hexadecanoic acid \\
\hline & & & Nonane \\
\hline & & & Decane \\
\hline \multirow[t]{2}{*}{2} & Worker bee brood & Dichloromethane & Heptacosane \\
\hline & & & Octacosane \\
\hline \multirow[t]{2}{*}{3} & Worker bee brood & Pentane + Acetone + & (9Z)-Octadec-9-enoic acid (Oleic Acid) \\
\hline & & Diethyl ether & $\begin{array}{c}\text { Hexadecanoic } \\
\text { acid }\end{array}$ \\
\hline \multirow[t]{5}{*}{4} & Drone brood & water + brine solution & 2-methylpropanoic acid or \\
\hline & & then extraction with diethyl & 4-hydroxybutan-2-one \\
\hline & & ether & Decane \\
\hline & & & Dodecane \\
\hline & & & Tetradecane \\
\hline \multirow[t]{8}{*}{5} & Adults bee & Hexane & (9Z)-Octadec-9-enoic acid (Oleic Acid) \\
\hline & & & (9Z)-Octadec-9-enoic acid methyl ester \\
\hline & & & 2,6,10-trimethyl-tetradecane \\
\hline & & & Octacosane \\
\hline & & & Hexacosane \\
\hline & & & Nonadecane \\
\hline & & & 3,5,24-trimethyl-tetracontane \\
\hline & & & Terpenes: limonene \\
\hline
\end{tabular}

oven at $50^{\circ} \mathrm{C}$ initial time, then gradient $8^{\circ} \mathrm{C} / \mathrm{min}$ to $220^{\circ} \mathrm{C}$ for $10 \mathrm{~min}$, then $20^{\circ} \mathrm{C} / \mathrm{min}$ to $240^{\circ} \mathrm{C}$ for 5 $\mathrm{min}$, isotherm $240^{\circ} \mathrm{C} 15 \mathrm{~min}$.

\section{CONCLUSION}

By GC-MS analysis of the extracts of biological material, the following were identified: different fatty acids and fatty acid methyl esters and many hydrocarbons with long chains, as well as some terpenes generally known in the nature as possible semiochemicals.

Biological tests (research in progress) are necessary to confirm the role of these organic compounds in interspecific communication in the hive. Substances identified will be tested in biological experiments regarding the behavioural response of the mite Varroa destructor.
Aknowledgements: This study was financed with the support of MEN-UEFISCDI, the programme "Parteneriate in domenii prioritare - PN II"; Project PN-II-PT-PCCA-2013-4-1947 in progress, contract no. 143/2014.

\section{REFERENCES}

1. Garrido C, Rosenkranz P. (2004). Volatiles of the honey bee larva initiate oogenesis in the parasitic mite Varroa destructor. Chemoecology,14, 193-197

2. Palacio MA, Rodriguez E, Goncalves L, Bedascarrasbure E, Spivak M. (2010) Hygienic behaviours of honey bees in response to brood experimentally pin-killed or infected with Ascosphaera apis. Apidologie 41, 602-612

3. Ziegelmann B. and Rosenkranz P. (2014), Pheromone composition for treating Varroa mite infestation, PCT patent WO 2014023733 A1. 